\title{
POST-MORTEM CHARACTERISATION OF ALUMINA-C REFRACTORY BRICKS WITH ORGANIC BOND FROM STEEL PRODUCTION: POTENTIALITY OF $\mathrm{Al}_{2} \mathrm{O}_{3}$ - MATERIAL RECOVERY
}

\author{
"BEATRICE PLEŠINGEROVÁ*, PAVOL VADÁSZ*, RASTISLAV KAMENSKÝ**, JÁN DERĎAK**, \\ JANA BOUNZIOVÁ***, EVA DEDINSKÁ*, MAREK VOJTKO**** \\ *Technical University of Košice, Faculty of Metallurgy, Metallurgy Institute, Letná 9, 042 00, Slovakia \\ **R.M.S a.s., Košice, Vstupný areál U.S.Steel, Košice 044 54, Slovakia \\ ***U.S.Steel Košice, s.r.o., USSE Research and Development, Vstupný areál U.S Steel, 04454 Košice, Slovakia \\ ****IMR SAS Košice. Watsonova 47, Slovakia \\ "E-mail: beatrice.plesingerova@tuke.sk
}

Submitted February 10, 2017; accepted March 20, 2017

\begin{abstract}
Keywords: Post-mortem characterisation, Spent refractories, Corundum, Size fraction, Leaching, Redistribution
The paper describes the post-mortem characterisation of spent class AC 70/5 refractory linings from steel ladles, focuses on the environmental impact of their dumping, and points to possibilities of reusing material that is less degraded by corrosion. The degradability of the spent refractories in water is an indicator of their degree of corrosion. Therefore the crushed refractory bricks were leached in water and a weakly acid medium $(\mathrm{pH}=5.95$ and 4.21 , respectively). The $\mathrm{pH}$ value, conductivity, redox potential and concentration of ions were measured in the leachates. New AC 70/5 material generates a pH value of leachates of around 8.5, while the alkalinity of leachates from spent brick material increases with the increasing content of lime-corroding compounds $(\mathrm{pH}=10$ - 12). Alkaline environments inhibit the release of heavy metal ions. Under the thin strongly corroded surface the refractory material deteriorates only slightly. When bricks are crushed, a redistribution of components into grainy fractions occurs. $\mathrm{C}$ and $\mathrm{MgO}$ are concentrated in the fine fraction (under $1 \mathrm{~mm}$ ) and $\mathrm{Al}_{2} \mathrm{O}_{3}$ in the coarse fractions $(1-2.5 \mathrm{~mm}$ ). In view of raw material prices it is desirable to proceed further with the recovery of grainy $\mathrm{Al}_{2} \mathrm{O}_{3}$.
\end{abstract}

\section{INTRODUCTION}

The cost of the refractory materials for linings of high-temperature aggregates is growing. The main reasons are the increasing prices of high-quality raw materials and their import from long distances. Bricks with greater corrosion resistance and long-term durability have reduced the number of repairs of furnace linings. Since the requirements on refractory quality are growing together with an increased demand for raw materials continuing attention is devoted to the raw materials and the production technologies of refractories. Corrosion processes, interactions of refractories with slags, molten metals, glass and corrosive gases are studied intensively [1-7].

The consumption of heat-resistant ceramic materials in the steel industry is high. For example, $1.2-1.5 \mathrm{~kg}$ of refractory linings applied in the convertor and pouring ladle are needed to produce 1 ton of steel, and $5-15 \mathrm{~kg}$ refractories for the electric arc furnaces are needed per 1 ton of steel $[8,9]$. During the production cycle about $35 \%$ of the refractory materials are dissolved by the molten metal and slags and the rest is landfilled or recycled [10].
Of course, any approach that raises the durability of the refractory materials saves raw material resources. Another possibility is the secondary utilisation of worn linings or their recovery, an approach that is rarely used in factories today, but indispensable for saving the raw materials in the future. In recent years a more comprehensive monitoring of the impact of different wastes on the environment and groundwater quality under landfills, and the escalated costs for landfilling, put urge metal producers to minimize the output of refractory wastes [11-13]. Therefore manufacturing companies begin to realize the potential of spent refractories to be recycled. Of course, if this option is to be used, it requires the companies to perform the general overhaul of the lining in close cooperation with the producers of refractory materials. Apart from free landfills, depending on the degree of degradation of the spent lining refractories, there are more options of their recycling and further use $[1,13-21]$ :

- reuse for manufacturing of the new refractory bricks and masses;

- use as additives to other ceramic masses and building materials; 
- use as slag conditioners or fuel source (because of the carbon content);

- use as back fill, landscape materials or for soil stabilisation and other purposes.

The success of refractory materials recovery depends on the technological possibilities of separating and cleaning the components. The mechanical properties of spent bricks, their ability to release particles and the degree of chemical contamination are important parameters, but the key factors for the realization of the recycling technologies are the simplicity and efficiency of the whole technological process and low cost.

The present paper deals with the spent bricks on the base of $\mathrm{Al}_{2} \mathrm{O}_{3}-\mathrm{MgO}-\mathrm{C}$ refractory materials, which were applied as working linings of steel ladles. These bauxitebased bricks with organic binder are characterized by an excellent resistance to molten metals, high temperature mechanical strength and resistance to thermal spalling and slag corrosion. The refractory bricks contain more than 5 wt. \% C and smaller amounts of the fine magnesia and antioxidant additive. The high cost of bauxite determines the cost of refractory bricks $[4,8]$.

The aim of this study was to characterize the spent bauxite refractories from the ladle lining and point to the possibility of separating the components into different particle size classes and extracting alkaline impurities by aqueous media.

\section{EXPERIMENTAL}

\section{Materials}

The bricks studied here are AC 70/5 class bricks which resist service temperatures of up to $1700^{\circ} \mathrm{C}$. Their bulk density is at least $2960 \mathrm{~kg} \cdot \mathrm{m}^{-3}$ and the cold crushing strength is $50 \mathrm{MPa}$ (STN EN 12475-4 [21]). Refractory bricks of the class $\mathrm{AC} 70 / 5$ containing $\geq 78 \mathrm{wt} . \% \mathrm{Al}_{2} \mathrm{O}_{3}$, $\geq 6.5 \% \mathrm{MgO}, 2.3 \% \mathrm{SiO}_{2}, 1.2 \% \mathrm{Fe}_{2} \mathrm{O}_{3}$ and $\geq 5 \% \mathrm{C}$ is produced from a mix of bauxite (size fractions 0-6 mm), brown corundum (particle size $<0.09 \mathrm{~mm}$ ) and $\mathrm{MgO}-$ clinker (size fractions $0-3.15 \mathrm{~mm}$ ).

The spent bricks were obtained from the lining of circuit "SOLP" steel ladles (after 198 casting runs), see Figure 1. One group of samples was prepared by crushing materials from the core of the spent bricks (labelled BB), the second from the surface (labelled BS), the removed corroded layer was approx. $20 \mathrm{~mm}$ thick. Reference grainy samples were prepared from new bricks (labelled $\mathrm{BN})$. These materials were crushed to a grain size smaller than $2.5 \mathrm{~mm}$. Part of the samples was divided into two size fractions $(0-1 \mathrm{~mm}$ and $1-2.5 \mathrm{~mm})$.

The measured specific surface (Quantachrome NOVA-1000; nitrogen gas, evaluation via the BET method), magnetic ratio (i.e. the weight faction of magnetic constituents, mainly metallic iron) and loss on ignition $\left(1000^{\circ} \mathrm{C} / 1 \mathrm{~h}\right)$ of grainy samples are shown in Table 1.

The chemical composition of the fractions $0-1 \mathrm{~mm}, 1-2.5 \mathrm{~mm}$ and $0-2.5 \mathrm{~mm}$, determined by the classical analysis methods, is shown in Table 2. Coarsegrained samples ( $1-2.5 \mathrm{~mm}$ ) were investigated by X-ray diffraction/XRD analysis (Rigaku MiniFlex 600) and the

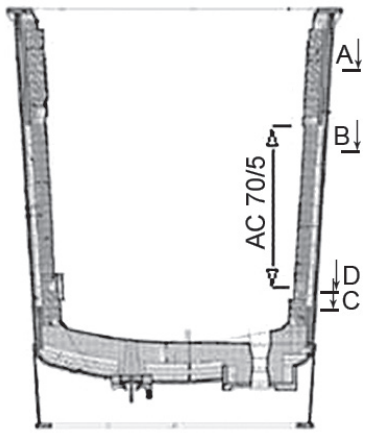

a)

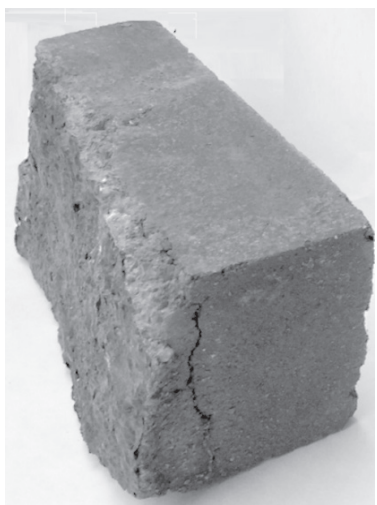

b)
Figure 1. Steel ladle with localization of AC 70/5 bricks [9] and spent brick.

Table 1. Basic characteristic of samples obtained by crushing spent AC 70/5 bricks.

\begin{tabular}{|c|c|c|c|c|c|}
\hline Sample from & Label & $\begin{array}{l}\text { Magnetic ratio } \\
\text { (wt. \%) }\end{array}$ & $\begin{array}{l}\text { Loss on ignition L.I. } \\
\text { (wt. } \%)\end{array}$ & $\begin{array}{l}\text { Colour change } \\
\text { after ignition }\end{array}$ & $\begin{array}{l}\text { Specific surface area }(\mathrm{Sa}) \\
\qquad\left(\mathrm{m}^{2} \cdot \mathrm{g}^{-1}\right)\end{array}$ \\
\hline core $0-2.5 \mathrm{~mm}$ & $\mathrm{BB}$ & $0-2$ & 8.79 & black $\rightarrow$ light grey & 2.10 \\
\hline surface $0-2.5 \mathrm{~mm}$ & $\mathrm{BS}$ & $6-22$ & 5.35 & black $\rightarrow$ grey & 2.05 \\
\hline
\end{tabular}

Table 2. Chemical analysis of particle size fraction of spent AC 70/5 brick material after comminution.

\begin{tabular}{lcccccccccccc}
\hline \multirow{2}{*}{ Samples } & \multicolumn{10}{c}{ Chemical analysis (wt. \%) } \\
\cline { 2 - 13 } & $\mathrm{Al}_{2} \mathrm{O}_{3}$ & $\mathrm{SiO}_{2}$ & $\mathrm{MgO}$ & $\mathrm{CaO}$ & $\mathrm{Fe}_{2} \mathrm{O}_{3}$ & $\mathrm{Na}_{2} \mathrm{O}$ & $\mathrm{K}_{2} \mathrm{O}$ & $\mathrm{S}$ & $\mathrm{MnO}$ & $\mathrm{Cr}_{2} \mathrm{O}_{3}$ & L.I. & Insoluble part \\
\hline BB 0-2.5 mm & 58 & 3.0 & 7.1 & 1.3 & 1.80 & 0.15 & 0.51 & 0 & 0.23 & 0.05 & 8.93 & 16.5 \\
$\mathrm{BB} \mathrm{0-1} \mathrm{mm}$ & 57 & 3.0 & 13.3 & 1.3 & 1.47 & - & - & - & - & - & 12.6 & 9.00 \\
$\mathrm{BB} \mathrm{1-2.5} \mathrm{mm}$ & 60 & 3.7 & 5.8 & 1.1 & 1.74 & - & - & - & - & - & 4.75 & 17.4 \\
BS 0-2.5 mm & 52 & 3.3 & 6.4 & 10.5 & 3.74 & 0.30 & 1.23 & 0 & 0.21 & 0.20 & $6 . .43$ & 13.2 \\
\hline
\end{tabular}

$B B$-from the core; $B S$ - from the surface layer; L.I. - Loss on ignition 
XRD records shown in Figure 2 were evaluated using the qualitative analysis software PDXL 2 and the ICCD mineral and ceramics database (Table 3 ). The grains in the brick fractions were investigated by EDS (Jeol JSM $7000 \mathrm{~F}$ with analytic systems EDX and EBSD) after coating with carbon (Table 4).

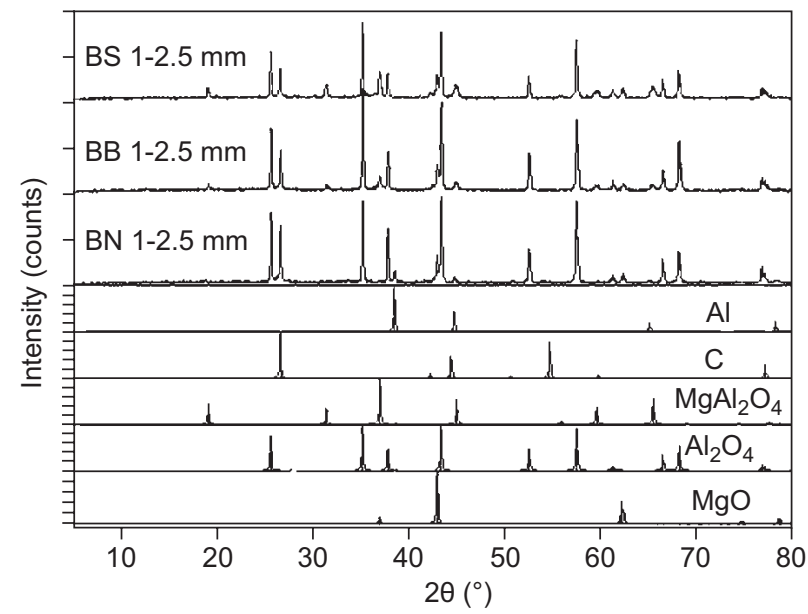

Figure 2. XRD pattern of coarse-grained sample from the AC $70 / 5$ bricks.

\section{Leaching test}

The samples were leached in deionized water $\left(\mathrm{pH}=5.95 \pm 0.05\right.$ (conductivity $\sigma=2-3 \mu \mathrm{S} \cdot \mathrm{cm}^{-1}$; oxidation/reduction potential $-\mathrm{ORP}=100 \mathrm{mV}$ ) and/or in weak acid solution $(\mathrm{pH}=4.21 \pm 0.05$; conductivity $18-20 \mu \mathrm{S} \cdot \mathrm{cm}^{-1}$; ORP $=245 \mathrm{mV}$ at $20^{\circ} \mathrm{C}$ ). The acid solution was prepared from dilute solution of sulphuric acid/nitric acid mix (weight ratio 6:4). The conditions of the leaching batch test are based on internationally recommended methods $[22,23]$. The batch tests were carried out with liquid-to-solid ratios $(\mathrm{L}: \mathrm{S})=10$ at room temperature. The liquid medium $(50 \mathrm{ml})$ was added to $5 \mathrm{~g}$ of the dry samples with defined size fractions into PE-bottles. The PE-bottles were stirred on a rotator (Multi RS-60 Biosan) at $15 \mathrm{rpm}$ during the tests. During leaching the $\mathrm{pH}$ value, conductivity (s) and ORP were measured (Digital pH/ORP/D.O.Multi-9310, Cond 311 SET2). After filtration of the leachates the concentrations of ions were measured by inductively coupled plasma-atomic emission spectroscopy (ICP-AES/iCAP 6000 Series). The tests were repeated $3-5$ times and average values are shown in Tables 5 and 7 and Figures 3 and 4 .

\section{RESULTS}

\author{
Characterisation of \\ spent refractory AC 70/5
}

The AC 70/5 bricks are applied without bonding mortar in the steel ladle. The infiltration of the slag into the corroded layer is several millimetres in depth. Cracks between the corroded surface layer and the less damaged brick core made the separation of layer from core bricks easier (see Figure 1). The sample from the surface (BS), strongly corroded by the molten metal and slag, contains magnetic components and shows a lower loss on ignition (Table 1). The colour and weight changes point to a content of carbon in the samples.

It should be mentioned that ductile particles (iron) larger than $2.5 \mathrm{~mm}$ have been excluded from the samples for the chemical analysis and subsequent leaching tests.

The results of the chemical analysis of $\mathrm{BB}$ and $\mathrm{BS}$ samples are shown in Table 2, which lists the values of the insoluble residues. It can be assumed that these residues mainly consist mainly of the thermally and chemically resistant $\mathrm{Al}_{2} \mathrm{O}_{3}$. The differences in contents of $\mathrm{CaO}$ and $\mathrm{K}_{2} \mathrm{O}$ between $\mathrm{BS}$ and $\mathrm{BB}$ samples confirm the strong

Table 3. Phase proportion of corundum, graphite and MA-spinel in AC 70/5 brick material.

\begin{tabular}{|c|c|c|c|c|}
\hline \multirow{2}{*}{ Phase name } & \multicolumn{4}{|c|}{ Content $(\%)$} \\
\hline & $\mathrm{BN} 1-2.5 \mathrm{~mm}$ & BB $1-2.5 \mathrm{~mm}$ & BB $0-2.5 \mathrm{~mm}$ & BS $1-2.5 \mathrm{~mm}$ \\
\hline Alpha $\mathrm{Al}_{2} \mathrm{O}_{3} /$ & $65 / 74$ & $62-73$ & $50-55$ & $(55-63)$ \\
\hline Graphite, C & $10-13$ & $8-10$ & $15-17$ & $8-9$ \\
\hline Periclase, $\mathrm{MgO}$ & (9) & (13) & $(13-16)$ & $(8-10)$ \\
\hline Spinel, $\mathrm{MgAl}_{2} \mathrm{O}_{4}$ & $4-6$ & $9-11$ & $16-18$ & $18-20$ \\
\hline $\mathrm{Al}$ antioxidant and $\mathrm{TiO}, \mathrm{TiO}_{2}$ & $(>2)$ & (2) & (2) & $(>1)$ \\
\hline
\end{tabular}

Table 4. Approximate content of elements in corundum grains from fraction of 1-2.5 mm (EDS - analysis/average values from at least 4 grains).

\begin{tabular}{lcccccccccc}
\hline \multirow{2}{*}{ Samples } & $\mathrm{9}$ & \multicolumn{10}{c}{ Content of elements (wt. \%) } \\
\cline { 3 - 12 } & $\mathrm{Al}$ & $(\mathrm{Si})$ & $\mathrm{Mg}$ & $\mathrm{Ca}$ & $\mathrm{Fe}$ & $\mathrm{Na}$ & $\mathrm{K}$ & $\mathrm{S}$ & $\mathrm{Ti}$ & $\mathrm{O}$ \\
\hline BN & 47,2 & $(2.0)$ & $<0.05$ & 0,2 & 0,6 & $<0.1$ & 0.4 & 0 & 3,4 & 44,5 \\
BB & 47.0 & $(2.5)$ & 0.8 & 0.8 & 0.8 & 0.2 & 0.7 & 0 & 2.3 & 44.8 \\
BS & 48.0 & $(2.5)$ & 0.5 & 1.28 & 0.7 & 0.3 & 0.7 & 0 & 1.4 & 43.4 \\
\hline
\end{tabular}


corrosion of the surface layer (BS). The brick cores (BB) have a much smaller content of $\mathrm{CaO}$ and higher contents of $\mathrm{Al}_{2} \mathrm{O}_{3}$ and combustible constituents (carbon). Comparing the content of the elements (oxides) in the fractions of the $\mathrm{BB}$ samples, a redistribution of $\mathrm{Al}_{2} \mathrm{O}_{3}$, $\mathrm{MgO}$ and combustible constituents (carbon) can be seen. The carbon and $\mathrm{MgO}$ are very fine and therefore they accumulated in the size class $0-1 \mathrm{~mm}$. The weight ratio of fractions $0-1 \mathrm{~mm}$ and $1-2.5 \mathrm{~mm}$ was approximately 50:50.

The XRD pattern and phase analyses of coarsegrained (1-2.5 mm) BN, BB and BS samples confirm the dominant content of corundum and graphite (Figure 2). Beside the phases of corundum and graphite, also periclase and MA-spinel and traces of $\mathrm{TiO} / \mathrm{TiO}_{2}$ and $\mathrm{Al}$ were detected (Table 3). The contents of MA-spinel in the sample increase in the order $\mathrm{BN}(1-2.5 \mathrm{~mm})<\mathrm{BB}$ $(1-2.5 \mathrm{~mm})<\mathrm{BB}(0-2.5 \mathrm{~mm})<\mathrm{BS}(1-2.5 \mathrm{~mm})$.

Results of elemental analysis (via EDS) of several particles from the $1-2.5 \mathrm{~mm}$ fractions of $\mathrm{BN}, \mathrm{BB}$ and BS samples, respectively, confirmed that $\mathrm{Al}_{2} \mathrm{O}_{3}$ grains of high purity are dominating. The average composition of the $\mathrm{Al}_{2} \mathrm{O}_{3}$ grains is listed in Table 4. Grains with a higher content of $\mathrm{MgO}$ were identified only exceptionally, and their composition was more variable than that of the $\mathrm{Al}_{2} \mathrm{O}_{3}$ grains. For comparison, also the analysis of $\mathrm{MgO}$ grains from the $\mathrm{BS}$ sample is given: $16 \% \mathrm{Al}:(1 \% \mathrm{Si})$ : $36 \% \mathrm{Mg}$ : 6\% Ca: $0.5 \mathrm{Fe}: 40$ wt. \% O, and traces of $\mathrm{Na}, \mathrm{K}$ and Ti. Since the samples for EDS analyses were polished with $\mathrm{SiC}$ powder without water and then coated with carbon, carbon is not included in the evaluations.

\section{Stability of spent AC 70/5 refractories in aqueous media}

The extraction of elements from the grainy samples (Table 1) has been carried out in a setup of batch leaching tests with deionized water $(\mathrm{pH}=5.95)$ and weak acid solution $(\mathrm{pH}=4.21)$ in the ratio $\mathrm{L}: \mathrm{S}=10$. The extractability of components is one indicator of the degree of corrosion of the spent refractories.

\section{One-stage batch leaching test in de-ionized water and weak acid water}

The changes of conductivity and $\mathrm{pH}$ value in the leachates during continuous leaching are given Figure 3. The conductivity of the extracts from of the unused brick
(BN) and the core of the worn brick (BB) are comparable and increase with the leaching time only slightly. Unlike that, the conductivity and also $\mathrm{pH}$ in the leachates from the brick surface (BS) increase very significantly at the beginning, but after $2 \mathrm{~h}$ the values approach a limit value asymptotically. The conductivity correlates well with the concentration of ions in the solution (Table 5, Figure 3). The differences between the leachates obtained from samples BB and BS are large, as a consequence of the aggressive effect on the refractory bricks by the corrosive metal melt at the service temperature (about $1500^{\circ} \mathrm{C}$ ).

In Table 5 the average values of ion concentrations in the leachates of the de-ionized water (initial $\mathrm{pH}=5.95$ ) and weak acid solution (initial $\mathrm{pH}=4.21$ ) after $24 \mathrm{~h}$ are compared. Since the leached components eliminate the difference of the initial $\mathrm{pH}$ of de-ionized water and weak acid solution quickly, the difference in the concentrations is relatively small. It seems that the sodium and potassium ions are released into the weak acid slightly more efficiently. The presence of sulphur ions in the extract confirms the content sulphates in the spent bricks.

The high concentrations of $\mathrm{Al}^{3+}$ and $\mathrm{Ca}^{2+}$ ions in the leachates from BS samples point to the deterioration of the surface by Ca-containing slag. It is likely that the strong alkaline leachates $(\mathrm{pH} \sim 12)$ are already saturated with the ions. For this reason, further tests with the alternative media were made.

$\mathrm{The} \mathrm{Pb}, \mathrm{Cu}$, and $\mathrm{Cr}$ ions have neither been detected in the de-ionized water nor in the weak acid solution, $\mathrm{Zn}$ ions were only observed in concentration less than $0.05 \mathrm{mg} \cdot \mathrm{l}^{-1}$.

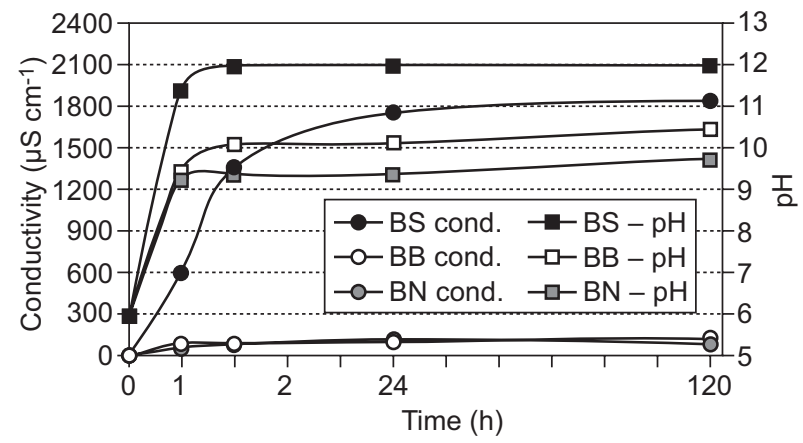

Figure 3. Changes of conductivity and $\mathrm{pH}$ in leachates with leaching time; samples of AC 70/5 refractory: $\mathrm{BN}$ - unused bricks, BB - core of spent brick, BS - surface of spent brick (leaching condition: de-ionised water with initial $\mathrm{pH}=5.95$ ).

Table 5. Concentration ions in leachates after $24 \mathrm{~h}$ of leaching.

\begin{tabular}{|c|c|c|c|c|c|c|c|c|c|c|}
\hline \multirow{2}{*}{ Samples } & \multicolumn{9}{|c|}{ Concentration of elements in leachates $\left(\mathrm{mg} \cdot \mathrm{l}^{-1}\right)$} & \multirow{2}{*}{$\mathrm{pH}$} \\
\hline & $\mathrm{Al}^{3+}$ & $\mathrm{Si}^{4+}$ & $\mathrm{Mg}^{2+}$ & $\mathrm{Ca}^{2+}$ & $\mathrm{Fe}^{+2 /+3}$ & $\mathrm{Na}^{+}$ & $\mathrm{K}^{+}$ & S-ion & $\mathrm{Zn}^{2+}$ & \\
\hline $\mathrm{BB}-\mathrm{W}$ & 10.9 & 0.47 & 1.96 & 15.6 & 0.07 & 0.56 & 2.16 & 1.08 & 0.04 & 10.08 \\
\hline $\mathrm{BB}-\mathrm{A}$ & 11.3 & 0.43 & 1.17 & 19.6 & 0.37 & 1.98 & 3.28 & 1.19 & 0.04 & 9.42 \\
\hline $\mathrm{BS}-\mathrm{W}$ & 436 & 1.00 & 0.40 & 246 & 0.02 & 0.91 & 2.97 & 1.01 & 0.04 & 11.85 \\
\hline $\mathrm{BS}-\mathrm{A}$ & 419 & 0.24 & 0.23 & 232 & 0.09 & 3.82 & 4.35 & 1.39 & 0.05 & 11.50 \\
\hline
\end{tabular}


In order to confirm whether $\mathrm{Pb}, \mathrm{Cu}, \mathrm{Zn}$ and $\mathrm{Cr}$ ions can be extracted from the spent $\mathrm{AC} 70 / 5$ bricks, leaching tests with strong acid solution $\left(\mathrm{H}_{2} \mathrm{SO}_{4}\right.$ and $\mathrm{HNO}_{3}$ in the ratio 6:4) with initial $\mathrm{pH}=1$ were carried out. The results listed in Table 6 indicate that the elements released from the bricks are able to push the $\mathrm{pH}$ to 3.77 and 4.55 for samples $\mathrm{BB}$ and $\mathrm{BS}$, respectively, during 1 hour of leaching. Under these conditions elevated contents of Fe, $\mathrm{Zn}$ and $\mathrm{Cu}$ ions in the leachates were indeed measured, but the $\mathrm{Pb}$ and $\mathrm{Cr}$ contents are still negligible.

Table 6. Concentration ions in leachates after $1 \mathrm{~h}$ of leaching (acid medium with initial $\mathrm{pH}=1$ ).

\begin{tabular}{|c|c|c|c|c|c|c|}
\hline \multirow{2}{*}{ Samples } & \multicolumn{5}{|c|}{ Concentration of ions in leachate $\left(\mathrm{mg} \cdot \mathrm{l}^{-1}\right)$} & \multirow{2}{*}{$\mathrm{pH}$} \\
\hline & $\mathrm{Cu}$ & $\mathrm{Zn}$ & $\mathrm{Cr}$ & $\mathrm{Pb}$ & $\mathrm{Fe}$ & \\
\hline BB & 0.35 & 11.3 & 0.00 & 0.00 & 98.2 & 3.70 \\
\hline BS & 0.68 & 3.30 & 0.05 & 0.00 & 108 & 4.55 \\
\hline
\end{tabular}

Differences in the composition of coarse and fine particle size of samples from the spent brick core

The small degree of penetration of the slag elements into the brick core (BB-sample in Table 2 and Figure 2) initiated a study of the redistribution of the elements into classes. The particle size fractions below and above $1 \mathrm{~mm}$ were analysed in greater detail. The observed differences in the leachate of the fine and coarse grain classes are listed in Figure 4 and Table 7. The samples were repeatedly leached in the weak acid medium $(\mathrm{pH}=4.21)$.

After replacing the medium by a fresh one, the alkalinity of the leachates increases repeatedly and the $\mathrm{pH}$ converges to the value obtained in the $1^{\text {st }}$ cycle. In the case of the fine $\mathrm{BB}$ samples, the $\mathrm{pH}$ is about 1 degree higher than in the coarse samples and the conductivity is more than 3 times higher (Figure 4a). In the case of BS samples from the corroded surface, the $\mathrm{pH}$ values of leachates are comparable (11.5 - 12).
The conductivity reflects the concentration of all ions in the leachate (Table 7). Preferentially, the $\mathrm{Na}^{+}$, $\mathrm{K}^{+}$and $\mathrm{S}^{\mathrm{x}}$ ions are extracted from both the fine and the coarse samples. Their concentration in the leachates decreases with the number of leaching cycles. The $\mathrm{Al}^{3+}$, $\mathrm{Si}^{4+}$ and $\mathrm{Ca}^{2+}$ content in the leachates depends on the

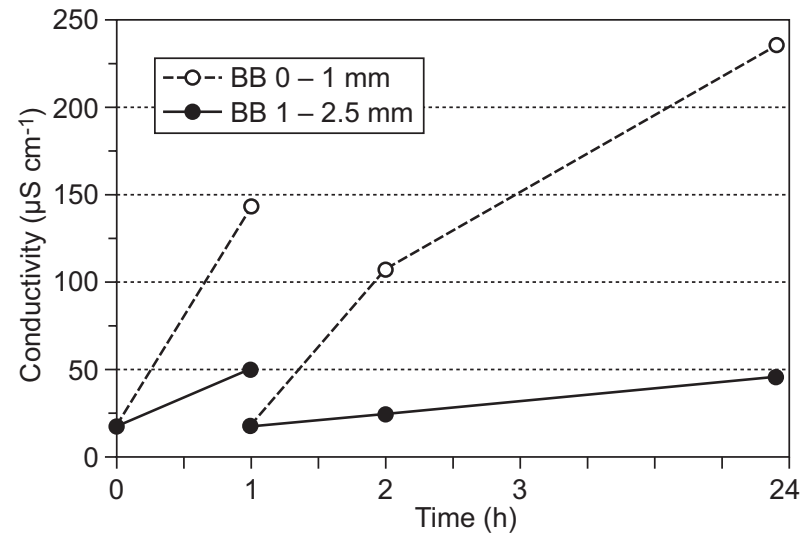

a)

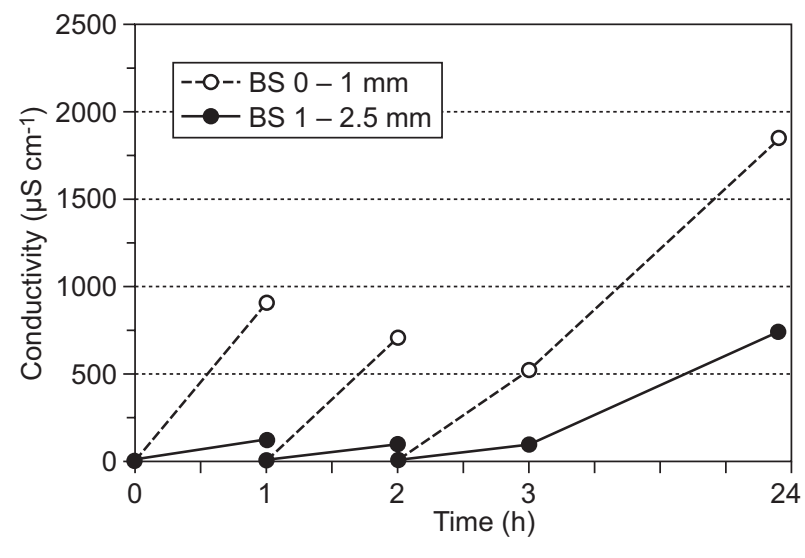

b)

Figure 4. Comparison of conductivity of the leachate from fine and coarse grainy samples a) BB and b) BS; medium: weak acid solution (initial $\mathrm{pH}=4.21$ ), replaced by a fresh solution after each leaching.

Table 7. Concentration ions in leachates from fine and coarse fractions of BB a BS at the end of leaching cycles; replacement of medium - weak acid solution $\left(\mathrm{pH}=4.21\right.$; content of $\mathrm{S}$ in initial solution $\left.=0.5 \mathrm{mg} \cdot \mathrm{l}^{-1}\right)$.

\begin{tabular}{|c|c|c|c|c|c|c|c|c|c|c|}
\hline \multirow{2}{*}{ Samples } & \multicolumn{9}{|c|}{ Concentration of elements in leachate $\left(\mathrm{mg} \cdot \mathrm{l}^{-1}\right)$} & \multirow{2}{*}{$\mathrm{pH}$} \\
\hline & $\mathrm{Al}^{3+}$ & $\mathrm{Si}^{4+}$ & $\mathrm{Mg}^{2+}$ & $\mathrm{Ca}^{2+}$ & $\mathrm{Fe}^{\mathrm{x}+}$ & $\mathrm{Na}^{+}$ & $\mathrm{K}^{+}$ & $\mathrm{S}^{\mathrm{x} \pm}$ & $\mathrm{Zn}^{2+}$ & \\
\hline BB $0-1 \mathrm{~mm} / 1 \mathrm{~h}$ & 13.3 & 1.85 & 2.77 & 31.7 & 0.07 & 2.48 & 2.16 & 3.62 & 0.15 & 9.90 \\
\hline BB $0-1 \mathrm{~mm} / 1-24 \mathrm{~h}$ & 34.8 & 2.77 & 1.48 & 47.2 & 0.15 & 0.51 & 1.51 & 1.61 & 0.25 & 10.76 \\
\hline BB $1-2.5 \mathrm{~mm} / 1 \mathrm{~h}$ & 5.35 & 0.84 & 2.63 & 51.8 & 0.13 & 1.32 & 0.96 & 1.62 & 0.07 & 8.80 \\
\hline BB $1-2.5 \mathrm{~mm} / 1-24 \mathrm{~h}$ & 6.89 & 0.72 & 2.10 & 7.39 & 0.10 & 0.32 & 0.82 & 1.05 & 0.08 & 9.83 \\
\hline BS $0-1 \mathrm{~mm} / 1 \mathrm{~h}$ & 88 & 1.75 & 0.39 & 163 & 0.02 & 7.10 & 4.42 & 2.66 & 0.24 & 11.66 \\
\hline BS $0-1 \mathrm{~mm} / 1-2 \mathrm{~h}$ & 100 & 1.71 & 0.69 & 139 & 0.05 & 2.22 & 0.6 & 2.11 & 0.39 & 11.55 \\
\hline BS $0-1 \mathrm{~mm} / 2-24 \mathrm{~h}$ & 106 & 3.56 & 0.09 & 329 & 0.01 & 3.20 & 1.11 & 3.15 & 0.03 & 12.00 \\
\hline BS $1-2.5 \mathrm{~mm} / 1 \mathrm{~h}$ & 17.5 & 0.79 & 1.00 & 24.5 & 0.10 & 2.11 & 1.08 & 1.51 & 0.13 & 10.38 \\
\hline BS $1-2.5 \mathrm{~mm} / 1-2 \mathrm{~h}$ & 20.4 & 0.55 & 0.92 & 24.1 & 0.05 & 1.01 & 0.22 & 0.98 & 0.33 & 11.39 \\
\hline BS $1-2.5 \mathrm{~mm} / 2-24 \mathrm{~h}$ & 113 & 1.71 & 0.67 & 145 & 0.10 & 1.86 & 0.89 & 2.55 & 0.12 & 11.45 \\
\hline
\end{tabular}


degree of the material deterioration by corrosion, the composition of grainy class, on the leaching time and on the $\mathrm{pH}$ of the solution established during the leaching.

\section{DISCUSSION}

Behaviour of spent corundum-carbon refractories as landfilled

The specific surface of the tested grainy samples $(0-2.5 \mathrm{~mm})$ is not determined in this case of leaching, because the fine carbon particles are responsible for higher value of the surface area (Table 1).

The chemical analysis of the leachates from the AC $70 / 5$ bricks confirmed that the primary materials have a tendency to move permanently the neutral and weak acidic water into the alkaline region $(\mathrm{pH}$ approximately 8.5).

Corrosion products in the thin surface layer of refractory bricks promote the high concentrations of $\mathrm{Ca}^{2+}$ and $\mathrm{Al}^{3+}$ ions in the extracts from BS samples (Tables 5 and 7). The shift of $\mathrm{pH}$ to the alkaline region $(11-12)$ is due to the high concentration of $\mathrm{Ca}^{2+}$ ions, which is incomparably higher than that of $\mathrm{Na}^{+}$and $\mathrm{K}^{+}$ions. It should be noted that a saturated solution of $\mathrm{Ca}(\mathrm{OH})_{2}$ generates a $\mathrm{pH}$ of 12.7 [24]. The corrosive sodium and potassium compounds are soluble in water and are preferentially washed out.

Elevated concentrations of the monitored heavy metals $(\mathrm{Pb}, \mathrm{Cu}, \mathrm{Cr})$ were not detected in the alkaline leachates. The concentrations of Fe and heavy metal ions were low both in the neutral and alkaline leachates [24]. However, if the samples are leached in the extremely acidic medium $(\mathrm{pH}=1)$, the $\mathrm{pH}$ moved to only $3.5-4.5$ during the first hour of leaching and higher concentrations of $\mathrm{Cu}^{2+} \mathrm{Zn}^{2+}$ and $\mathrm{Fe}^{2 / 3+}$ were measured (Table 6).

Strongly alkaline solutions are corrosive to silicates and aluminosilicates and the slag compounds (Al-Si-O) and $\mathrm{Al}_{2} \mathrm{O}_{3}$ - refractory materials will be attacked under such conditions. There is mutual influence in the multi-component solution and a possibility of coprecipitation. A precipitation process depends on several conditions, mainly the concentration of admixtures, the $\mathrm{pH}$ established and the temperature. During leaching, when the medium (Table 7) was replaced, the redox reduction potential of the leachates fluctuated from -60 to $30 \mathrm{mV}\left(\mathrm{t}=20^{\circ} \mathrm{C}\right)$. For the measured concentration of $\mathrm{Al}^{3+}=100 \mathrm{mg} \cdot l^{-1} ; \mathrm{Ca}^{2+}=148 \mathrm{mg} \cdot l^{-1}, \mathrm{Si}^{4+}=1.4 \mathrm{mg} \cdot l^{-1}$, $\mathrm{S}^{\mathrm{x}}=1.6 \mathrm{mg} \cdot \mathrm{l}^{-1}$ and $\mathrm{Mg}^{2+}=2.4 \mathrm{mg} \cdot \mathrm{l}^{-1}, \mathrm{pH}$ values in the range $10-12$ and $E=(-60$ to 30$) \mathrm{mV}$ the precipitation of calcium-alumina-silicate hydrates precipitation has been predicted (calculated by HSC software [25]). The precipitation processes are highly complicated. In particular, the presence of $\mathrm{CO}_{3}{ }^{2-}$ in water will promote the precipitation of hydrogen-carbonates. Slightly alkaline $\mathrm{pH}$ prevents the release of the heavy metals into the solution.
Recovery of spent

AC 70/5 refractory

To recover the corundum material from the $\mathrm{AC} 70 / 5$ refractory after the use requires crushing the spent bricks to particles size corresponding to the input granularity of the $\mathrm{Al}_{2} \mathrm{O}_{3}$ material. An advantage is that the most severely damaged parts (at the brick surface) have different mechanical and magnetic properties and are therefore easy to separate from the rest.

The fractions obtained by crushing showed that carbon and $\mathrm{MgO}$ accumulate in the small size fraction $(<0.1 \mathrm{~mm})$ and the $\mathrm{Al}_{2} \mathrm{O}_{3}$ accumulate in the large size fraction $(1-2.5 \mathrm{~mm})$, Table 1 .

The corroded surface has a composition close to the slag conditioners and a higher content of Fe. The presence of Fe-compounds is advantageous from the viewpoint of magnetic properties, while the carbon contained can act as heat source (Table 2).

$\mathrm{X}$-ray diffraction analysis showed the differences in the phase composition of the $1-2.5 \mathrm{~mm}$ fractions of $\mathrm{BN}, \mathrm{BB}$ and $\mathrm{BS}$ samples, respectively (Figure 2). The comparison of the phase contents listed in Table 3 indicates a higher amount of spinel $\left(\mathrm{MgAl}_{2} \mathrm{O}_{4}\right)$ in the spent bricks, as a result of the high-temperature of the bauxite components with fine $\mathrm{MgO}$ in the refractory mix. The detected phases are in accordance with results of other authors [4] work, who studied the high-temperature processes in $\mathrm{Al}_{2} \mathrm{O}_{3}-\mathrm{MgO}-\mathrm{C}$ refractory, including the changes in the chemical and phase composition.

The EDX pilot analyses of grains $>1 \mathrm{~mm}$ point to the purity of the dominant corundum grains (Table 4). The chemical analyses and the leaching tests with grainy samples from the spent bricks in the aqueous medium have shown a low degree of degradation in the brick core material. The Na- and $\mathrm{K}$ - content can be eliminated by washing (Tables 7 and 8 ) and the carbon can be removed by combustion of the grainy sample.

Utilization of the $\mathrm{Al}_{2} \mathrm{O}_{3}$-rich fraction depends on the phase and chemical composition, the impurities, the thermal stability of the contaminations, the density, shape and size of the particles.

\section{CONCLUSIONS}

The spent AC 70/5 bricks from steel ladle linings are strongly corroded on the working surface. The $\mathrm{Ca}^{2+}$ content is high in the thin surface layer. A low amount of Na-, $\mathrm{K}$ - and S-compounds is present in the core and surface of the spent bricks.

AC 70/5 refractory material from new, unused brick keeps the $\mathrm{pH}$ value in the leachate at approximately 8.7. The spent refractories that have undergone corrosion have a higher capacity to shift the $\mathrm{pH}$ into the alkaline region (11.5-12). The $\mathrm{pH}$ shifts into the alkaline region mainly because of the high concentration of $\mathrm{Ca}^{2+}$ ions 
in the $\mathrm{Ca}-\mathrm{Al}-\mathrm{Si}-\mathrm{O}$ corrosion products, from where they are released, along with the $\mathrm{Al}^{3+}$, during the leaching. The $\mathrm{pH}$ controls the solubility of the solids, the dissolution of heavy metals being strongly inhibited in the alkaline region. The leaching tests confirm that landfilling AC 70/5 spent refractory materials will not have any negative-impact on the pollution of groundwater with toxic metals and also that the material under the thin corroded surface layer is not damaged too much.

In case of the recovery of the parts of the spent brick, firstly, the most corroded parts of the bricks must be mechanically separated during the demolition process. The advantage is that the bricks are not bonded with binder any more. The components redistribute into coarse and fine fractions during the disintegration. The $\mathrm{Al}_{2} \mathrm{O}_{3}$ are concentrated in the coarse fraction ( $1-2.5 \mathrm{~mm}$ ). The sodium and potassium contained in this fraction can be reduced partially by washing with water. On the other hand, the fine fraction contains more combustible carbon.

The simplicity and efficiency of the treatment processes which lead to the recovery of the specific property fraction and the low costs are determining factors for the possible realization of this kind of material recycling.

\section{Acknowledgement:}

This publication was supported by the project VEGA 1/0578/16 and the results obtained are part of the solution from this grant project.

\section{REFERENCES}

1. Malfliet A,. Lotfian S., Scheunis L., Petkov V., Pandelaers L., Jones P.T., Blanpain B. (2014): Degradation mechanisms and use of refractory linings in copper production processes: A critical review. Journal of the European Ceramic Society, 34(3), 849-876. http.//dx.doi.org/10.1016/ j.jeurceramsoc.2013.10.005

2. Jansson S., Brabie V., Bohlin L. (2004): Corrosion mechanism and kinetic behaviour of refractory materials in contact with $\mathrm{CaO}-\mathrm{Al}_{2} \mathrm{O}_{3}-\mathrm{MgO}-\mathrm{SiO}_{2}$ slags. In. International Conference „Molten Slags Fluxes and Salts“, The South African Institute of Mining and Metallurgy, 341-347.

3. Chen L., Malfliet A., Jones P.T., Blanpain B., Guo M. (2016): Degradation mechanisms of alumina-silica runner refractories by carbon steel during ingot casting process. Ceramics International, 4(8), 10209-10214. http://dx.doi. org/10.1016/j.ceramint.2016.03.139

4. Munoz V., Tomba Martinez A.G. (2012): Thermal evolution of $\mathrm{Al}_{2} \mathrm{O}_{3}-\mathrm{MgO}-\mathrm{C}$ refractories. $11^{\text {th }}$ International Congress on Metallurgy \& Materials SAM/CONAMET 2011. Procedia Materials Science, 1, 410-417. doi:10.1016/j.mspro. 2012.06.055

5. Yang J-Z., Fang M-H., Huang Z-H., Hu X-Z., Liu Y-G., Sun H-R., Huang J-T., Li X-Ch. (2012): Solid particle impact erosion of alumina based refractories at elevated temperatures, Journal of the European Ceramic Society, 32(2), 283-289. http://dx.doi.org/10.1016/j.jeurceramsoc. 2011.08.017

6. Vadász P., Tomášek K., Rabatín R. (1995): Dynamické korózne skúšky magnéziových, magnézio-chromitých a magnézio-uhlíkatých stavív. Hutnické listy, 11, 25-27 [in Slovak].

7. Schutte M. (2010): Refractory recycling earning your environmental brownie points. The Southern African Institute of Mining and Metallurgy Refractories conference.75-85.http://www.saimm.co.za/Conferences/Refractories2010/75-86_Schutte.pdf (accessed 2016-13-04)

8. Staroň J., Tomšu F. (2000): Žiaruvzdorné materiály, výroba, vlastnosti a použitie. 2. Edit. Slovmag,a.s. Lubeník SMZ, a.s. Jelšava, Keramika, a.s. Košice. p.445. [in Slovak].

9. Chudíková D., Kamenský R., Karičková A., Štulrajter S. (2013): Vymurovka oceliarenskej panvy z materiálov z produkcie spoločnosti RMS a.s. Košice. In.: Oceláři. Konference 4.-5.4 Karlova Studánka. http://konsys-t. tanger.cz/files/proceedings/13/reports/1369.pdf (accessed 2017-02-01) [in Slovak].

10. Roberts J. (2015): European refractories recycling-current trends and prospects. In.: $14^{\text {th }}$ Biennial Worldwide Congress UNITECR 2015, Proceeding 123.

11. Bradley M. (2015): Recycling of spent refractories. In.: $14^{\text {th }}$ Biennial Worldwide Congress UNITECR 2015, Proceeding 23.

12. Ferreira G., López-Sabirón A M., Aranda J., Mainar-Toledo M.D., Aranda-Usón A. (2015): Environmental analysis for identifying challenges to recover used reinforced refractories in industrial furnaces. Journal of Cleaner Production, 38(2) 242-253. http.//dx.doi.org/10.1016/j. jclepro.2014.04.087

13. Fang H., Smith J.D., Peaslee K.D. (1999): Study of spent refractory waste recycling from metal manufacturers in Missouri. Resources Conservation and Recycling, 25(2), 111-124. http://dx.doi.org/10.1016/S0921-3449(98)00059-7

14. Nakamura Y., Hirai, N., Tsutsui, Y., Uchinokura K. (1999): Recycling of refractories in the steel industry. Industry Ceramic, 19, 111-114.

15. Viklund-White C., Ruotanen K., Gehor S. (2001): Spent ladle refractories characterisation and reuse in new refractory materials. In: International Colloquium on Refractories. Aachen. Germany, 86-91.

16. Richter F., Nemčok J. (2015): Využívání speciálních druhotných surovin. In: Suroviny 2015, Silikátová společnost České republiky z.s. 1-3. [in Czech].

17. Hanagiri S., Matsui T., Shimpo A., Aso S., Inuzuka T., Matsuda T., Sakaki S., Nakagawa H. (2008): Recent improvement of recycling technology for refractories. Nippon steel technical report. 98, 93-98.

18. Valoref A.O. (1998): Recovery and recycling of scrap refractories. World Ceramics \& Refractories, 9, 13-16.

19. Simon F-G., Adamczyk B., Kley G. (2003): Refractory materials from waste. Materials Transactions, 44(7), 12511254.

20. Malenšek N., Ducman V., Mirtič B. (2015): Recycled granulate obtained from waste alumina-rich refractory powder by the cold bonding process. Ceramic International, 41, 8996-9002. http://dx.doi.org/10.1016/j.ceramint. 2015.03.214

21. Classification of dense shaped refractory products. Part 4 (2001): Special products, STN EN 12475-4. 
22. Toxicity characteristic leaching procedure. Washington: EPA. Method 1311 (1992) p.35.

23. Synthetic precipitation leaching procedure. Washington: EPA. Method 1312 (1994) p.30

24. Plešingerová B., Fedoročková A., Jádi N., Sučik G. (2015): Comparison of the Ability of Limestone and Concrete to
Remove Heavy Metal Ions from Contaminated Water. Acta Metallurgica Slovaca, 21(3), 236-246, doi:10.12776/Ams. V21i3.59.

25. Roine A., Lamberg P., Mansikka-Aho J., Bjőrklund P., Kentala J.P., Talonen T. (2011): HSC Chemistry 7.11, software Outotec. Research Center 1974-2011 Finland. 